\title{
Rice (Oryza sativa) and chickpea (Cicer aritinum L) relay intercropping systems in an additive series experiment in rain fed lowland ecosystem of Fogera vertisols
}

\author{
Yayeh Bitew, Fekremariam Asargew \\ Agronomist, Adet Agricultural Research Centre, Amhara Agricultural Research Institute, P. O. Box 08, Bahir Dare, Ethiopia
}

Email address:

yayehbitew@gmail.com (Y. Bitew)

To cite this article:

Yayeh Bitew, Fekremariam Asargew. Rice (Oryza Sativa) and Chickpea (Cicer aritinum L) Relay Intercropping Systems in an Additive Series Experiment in Rain Fed Lowland Ecosystem of Fogera Vertisols. Science Research. Vol. 2, No. 6, 2014, pp. 179-184.

doi: $10.11648 /$ j.sr.20140206.15

\begin{abstract}
Study on rice as a main crop and chickpea as a companion crop relay intercropping in an additive series experiment in rain fed lowland ecosystem of Fogera vertisols was conducted for two consecutive years to test the rice-chick pea relay intercropping planting method and to determine the optimum proportion for component crops in rice- chick pea relay intercropping on transplanted rice. The experiment was conducted in randomized block design with three replications. Five seed rates of chick pea relayed intercropped in between rows of transplanted rice and one sole rice were tested i.e. full recommended seed rate of chick pea relay intercropped in between rows of transplanted rice, two-third of the recommended seed rate of chick pea relay intercropped in between rows of transplanted rice, two-third of the recommended seed rate of chick pea relay intercropped in between alternate rows of transplanted rice, half of the recommended seed rate of chick pea relay intercropped in between rows of transplanted rice, half of the recommended seed rate of chick pea relay intercropped in between alternate rows of transplanted rice and the sole transplanted rice used as comparison. Rice yield and yield component data were statistically subjected to analysis of variance using SAS-JMP-5 software. All growth, yield and yield component of rice did not significantly affected by additive relay intercropping and seed proportion in rice-chickpea relay intercropping systems. However, the study conducted for two consecutive years at all test sits confirmed that chick pea after twenty to thirty days from the planting time was completely dried and unable to gave seed yield from rice-chickpea relay intercropping experiment. Hence, under current crop management practice of rice at Fogera vertisol areas, chickpea cannot replace the grass pea in rice-grass pea relay intercropping system (farmers practice); and relay intercropping of chickpea with rice is not economically important for farmers to increase the yield potential and land use efficiency. It needs intensive Agronomy research on rice-chickpea intercropping systems and breeding on both component crops.
\end{abstract}

Keywords: Rice, Chickpea, Relay Intercropping

\section{Introduction}

Relay cropping system refers to growing two or more crops simultaneously during part of the life cycle of each. A second crop is planted after the first crop has reached its reproductive stage of growth but before it is ready for harvest [1]. A greater stability of yield over different seasons could be derived through the use of relay cropping. Because the lower period competition, relay cropping generally can provide higher relative yield totals than mixed or row intercropping [2]. Relay planting is practiced primarily to gain time for multiple cropping, to plant the subsequent crops at their optimum planting date when the current crop harvest is delayed [3], to avoid moisture stress in the post rainy season crops, to avoid labor peaks at better control of soil erosions, improvement in human nutrition, and crop residue quality for feed and risk aversion in case of failure of one crop.

On the other side, a monoculture is the agricultural practice of producing or growing a single crop or plant species over a wide area and for a large number of consecutive years. Monocultures can lead to the quicker spread of pests and diseases, where a uniform crop is susceptible to a pathogen [4]. 
Rice, the most important cereal in the world, and chickpea (Cicer arietinum L.), the third most important pulse crop plays a vital role in global agricultural economy [5]. Rice is one of the important staple foods and its production area has been increasing year after year in Fogera areas [6]. Fogera plain contributes $32 \%$ of rice production in the country [7]. Farmers in Fogera plain use dry seed broadcast planting method for rice production [8]. It is the main crop that has been produced mainly in mono-cropping systems for many years in Fogera areas. Rice and sugarcane are two crops that have been produced in mono-cropping systems for many years in the tropics [4]. Recently, farmers in Fogera areas practiced traditional rice as a main crop-grass pea as a companion crop relay intercropping planting method to increase yield per unit area. However, management of ricerelay intercropped with legume to maximize crop production follows simple natural principles, and its practice is limited only by the rice-grass pea relay cropping system. Moreover, grass pea is a low price crop in the region and hence it is very economical to replace grass pea with chick pea. Though, ricechick pea relay intercropping planting method is not practiced in rice producing areas of the country, it is essential to test this practice at farmers' field. Therefore, the objective of this experiment were to test the rice-chick pea relay intercropping planting method and to determine the optimum proportion for component crops in rice- chick pea relay intercropping on transplanted rice.

\section{Methods and Materials}

\subsection{Descriptions of the Experimental Area}

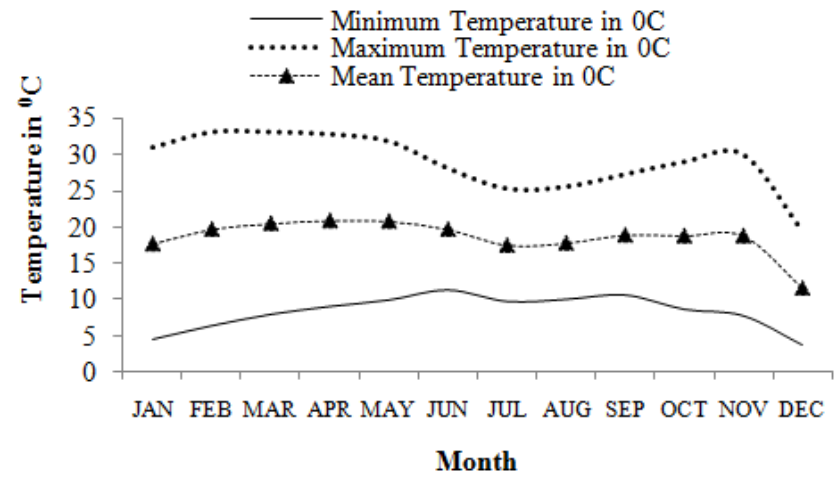

Figure 1. Minimum, Maximum and Mean Temperature $\left({ }^{\circ} \mathrm{C}\right)$ pattern at Fogera district.

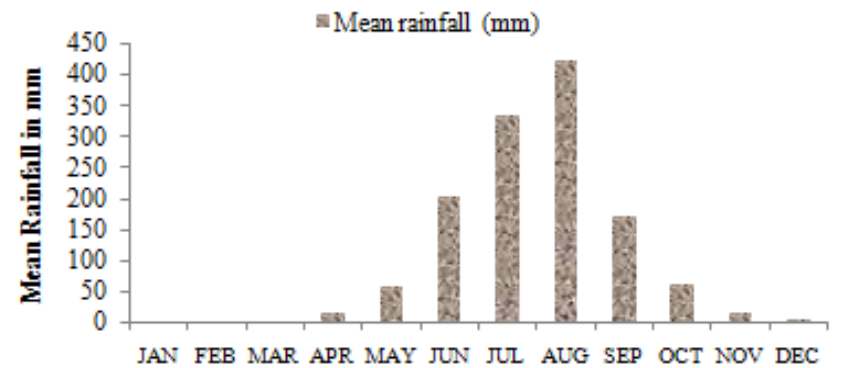

Month

Figure 2. Rain fall $(\mathrm{mm})$ pattern at Fogera district.
The experiment was conducted in rain fed lowland ecosystem in Fogera vertisols at three sites for two consecutive main cropping seasons (2011-2012). Fogera is situated $60 \mathrm{~km}$ North-East of Bahir Dar Town, South Gonder, Amhara Region. The experimental site is located at Latitude $13^{\circ} 19^{\prime}$ and Longitude $37^{\circ} 03^{\prime}$ and on an altitude of 1815 m.a.s.l. The monthly temperature and rainfall for the experimental site are indicated in Figure 1 and 2. The average climatic data of Woreta shows that the mean annual minimum temperature is $11.5^{\circ} \mathrm{c}$ and the mean annual maximum temperature is $27.89^{\circ} \mathrm{C}$ and the annual mean temperature nearly $18.3{ }^{\circ} \mathrm{c}$. As indicated in Figure 2 rainfall of the area is uni-modal, usually occurring during June to October, and average annual rainfall reached to $1300 \mathrm{~mm}$ [9]. According to [10], the soil on which the field experiment was conducted is classified as Pellic Vertisol. Analysis of composite surface soil samples collected from the experimental field indicated that the soil is moderately acidic ( $\mathrm{pH}$ in 1:1 soil: water ratio of 5.6$)$ and clayey (71.3\% clay). The surface soil was high in total $\mathrm{N}(0.28 \%)$, organic carbon (3.0\%), percent base saturation $(79.4 \%)$, cation exchange capacity (52.9 cmolc $\mathrm{kg}-1)$ and in Olsen extractable available P (36.2 mg 1-1), and medium (265.2 mg 1-1) in available $\mathrm{K}$ contents [10].

\subsection{Treatments and Experimental Design}

The experiment was conducted in randomized block design with three replications. Plot size of $5 \mathrm{~m}$ length and $4 \mathrm{~m}$ width was used. The distance between plots and replication were $1 \mathrm{~m}$ and $1.5 \mathrm{~m}$, respectively. Five seed rates of chick pea (Shasho) relayed intercropped in between rows of transplanted rice (X-Jigena)) and one sole rice were tested i.e.:

1. T1=Full recommended seed rate of chick pea relay intercropped in between rows of transplanted rice

2. $\mathrm{T} 2=$ Two-third of the recommended seed rate of chick pea relay intercropped in between rows of transplanted rice

3. T3=Two-third of the recommended seed rate of chick pea relay intercropped in between alternate rows of transplanted rice

4. T4=Half of the recommended seed rate of chick pea relay intercropped in between rows of transplanted rice

5. T5=Half of the recommended seed rate of chick pea relay intercropped in between alternate rows of transplanted rice).

6. $\mathrm{T} 6=\mathrm{The}$ sole transplanted rice used as comparison.

\subsection{Seedling preparation and cultural practices}

Seedlings of X-Jigna variety was raised on farmers 'fields. To raise seedlings for the transplanting treatment, soil and rice husk were mixed at volume ratio of $8: 1$ and then a $5 \mathrm{~cm}$ thick layer of the mixture was spread on the plastic covered seed bed. The rice seeds were broadcasted at a rate of $15 \mathrm{~kg}$ $/ 150 \mathrm{~m}^{2}$ seed bed and the seeds were covered with a thin layer of soil and dry grass. The grass was removed when the seeds 
start to emerge. The seed bed was watered daily both in the morning and at night till transplanting. Transplanting was conducted when the rice seedling was reached 4-leaf stage (about 25-30 days after emergence) with a spacing of $25 \mathrm{~cm}$ x $20 \mathrm{~cm}$ planted ( 3 seedlings per hill) at a depth of $3 \mathrm{~cm}$ on each experimental field. For rice, a Fertilizer rate of $69 / 23 \mathrm{~kg}$ $\mathrm{N} / \mathrm{P}_{2} \mathrm{O}_{5} \mathrm{ha}^{-1}$ was applied. One-third of nitrogen and all phosphorus were applied a few days after transplanting (just after the seedlings recovered from the transplanting shock). The other two-third of nitrogen was applied at tillering stage. Chick pea was relay intercropped in broad-casting in between rows of rice at a seed rate of $75 \mathrm{~kg} / \mathrm{ha}$ and at a depth of $3 \mathrm{~cm}$ when rice was attained at maturity and at the time of appropriate moisture level of the soil. For chickpea at planting $46 \mathrm{P}_{2} \mathrm{O}_{5} \mathrm{ha}^{-1}$ was used.

\section{Result and Discussions}

\subsection{Rice Growth, Yield and Yield Component}

Table 1. Results of analysis of variance for the two years combined effect of rice-chickpea relay intercropping on rice growth, yield and yield components (2011-2012).

\begin{tabular}{|c|c|c|c|c|c|}
\hline $\begin{array}{l}\text { Treatments and } \\
\text { statistics }\end{array}$ & $\begin{array}{l}\text { Grain yield } \\
\text { (kg/ha) }\end{array}$ & $\begin{array}{l}\text { Number of tillers/ } \\
\text { hill of rice }\end{array}$ & $\begin{array}{l}\text { Number of fertile } \\
\text { panicles/ hill of rice }\end{array}$ & $\begin{array}{l}\text { Plant height }(\mathrm{cm}) \text { of } \\
\text { rice }\end{array}$ & $\begin{array}{l}\text { Thousand seeds weight } \\
\text { (g) of rice }\end{array}$ \\
\hline $\mathrm{T} 1$ & 4499 & 8.64 & 132 & 90.5 & 25.82 \\
\hline $\mathrm{T} 2$ & 4529 & 6.91 & 129 & 88.32 & 25.57 \\
\hline T3 & 4618 & 6.55 & 131 & 91.71 & 25.93 \\
\hline $\mathrm{T} 4$ & 4624 & 7.62 & 127 & 89.36 & 25.58 \\
\hline T5 & 4622 & 8.39 & 133 & 89.51 & 25.39 \\
\hline T6 & 4541 & 7.66 & 133 & 86.8 & 25.48 \\
\hline $\operatorname{LSD}(5 \%)$ & NS & NS & NS & NS & NS \\
\hline $\mathrm{CV} \%$ & 13.4 & 17.2 & 12.5 & 6.7 & 3.5 \\
\hline
\end{tabular}

Notes: Values (means) not connected by different superscript letters are not significantly $(\mathrm{P}>0.05)$ different within columns according to Tukey-HSD tests. T1 $=$ Full recommended seed rate of chick pea relay intercropped in between rows of transplanted rice; T2=Two-third of the recommended seed rate of chick pea relay intercropped in between rows of transplanted rice; T3=Two-third of the recommended seed rate of chick pea relay intercropped in between alternate rows of transplanted rice; $\mathrm{T} 4=$ Half of the recommended seed rate of chick pea relay intercropped in between rows of transplanted rice; T5=Half of the recommended seed rate of chick pea relay intercropped in between alternate rows of transplanted rice and T6=The sole transplanted rice used as comparison.

Study on rice-chickpea relay intercropping in an additive series experiment in rain fed lowland ecosystem of Fogera vertisols are presented in this paper. Results of combined analysis of variance across years showed that all growth, yield and yield component of rice (Number of tillers/ $\mathrm{m} 2$, Grain yield (kg/ha), Number of Fertile panicles/ m2, Plant height (cm), 1000 kernel wt.(g)) did not significantly affected $(\mathrm{P}>0.05)$ by rice-chickpea relay intercropping systems and seed proportion (seeding ratio) (Table 1).This experiment gave an average yield of 4499-4624 kg/ha (Table 1). This might be due to early planting of rice in relay intercropping system takes advantage in peak resource demands for nutrients, water, and sunlight for all treatments. Similarly [12] and [13] reported that intercropping crops that have feature staggered planting and maturity dates or development periods takes advantage of variations in peak resource demands for nutrients, water, and sunlight. Selecting crops with different planting and maturity dates (lupine and finger millet) can also assist staggered harvesting and separation of grain commodities [14]. Moreover, even though, resource competition between two crops planted in relay cropping system is very low [15], the present study showed that rice grain yield had not different in all treatments (planted in different seeding ratios or seed proportions) probably due to complete failure of chickpea at mid developmental stage during rice-chickpea relay intercropping system.

\subsection{Chickpea Growth, Yield and Yield Component}

The effect of rice-chickpea relay intercropping on the yield and yield component of rice and was studied in depth for two years at three sites per location in high rice production potential areas of Ethiopia (Fogera). The results of an experiment for two consecutive years at all test sits confirmed that chick pea was fully emerged and showed normal growth for 15 days from the planting time. However, after fifteen days from the planting time chickpea plant population at all plots, sites and in both years were wilted. Nearly, after twenty to thirty days from the planting time the crop was completely dried and unable to generate any data (yield and yield component of chickpea) from rice-chickpea relay intercropping experiment. This is not due to diseases 
and insect pest damaged but it might be due to three main important reasons: problem of plant architecture, narrow plant spacing (mainly row spacing) and extremely high temperature in the area.

\subsubsection{Plant Architecture}

When designing an intercropping scheme, there are four components to consider: spatial arrangement, plant density, maturity date and plant architecture. Plant architecture is a commonly used strategy to allow one member of the mix to capture sunlight that would not otherwise be available to the others. Increased yields of some crops have resulted from indirect selection of plant architectural traits related to yield. Widely spaced corn plants growing above an under storey of beans and pumpkins is a classic example [12]. More efficient use of light can be attained by careful spatial arrangements of multi-storey cropping with tall and short crops, provided the short crops are adapted to low light intensities. In the present experiment, chickpea was planted nearly when rice was at maturity stage. However, chickpea produced no seed in an intercrop with rice due to its failure to growth and flower in the shade of a full rice canopy. Similar study in different crops done by [16] who reported that Caribbean stylo (Stylosanthes hamata cv. Verano) produced little seed in an intercrop with maize due to its failure to flower in the shade of a full maize canopy.. This study examines the potential relationship between plant architecture and yield for a legume grown under intercropping [17]

\subsubsection{Row Spacing}

The other most important reason why chickpea was completely failed is that transplanted rice was planted in 20 $\mathrm{cm}$ between hills with in rows and $25 \mathrm{~cm}$ between rows which is very narrow to conduct management practices for chickpea. Relay cropping is not possible under the present method of planting rice in $20 \times 20 \mathrm{~cm}$ hills because of narrow row spacing on one hand and intensive binding up of the soil by root mass of closely growing rice plants on the other [18]. The results of [18] further led to the conclusion that rice should preferably be planted in $60 \mathrm{~cm}$ apart triple row strips as it not only facilitates relay cropping but also gives total yield/ha comparable to the conventional planting system in 20 × $20 \mathrm{~cm} /$ hills which does not permit management practices and easy planting of relay crops.

\subsection{Extremely High Temperature}

Chickpea is one of the essential semi-arid tropical legume crops [19]. In Ethiopia it is mainly grown during the postrainy season on stored soil moisture; in this instance the crop is exposed to terminal drought which is accompanied by rising temperatures. Recent climate data from field experiments in Fogera plain during sowing and growth time after the rainy season (end of September to January) showed a mean temperature of $28{ }^{\circ} \mathrm{C}$ (Figure 2). Sowing temperature is an important determinant of yield, and will become a significant constraint should predicted climate change lead to higher future sowing temperatures. Likewise, [20] reported that chickpea may also experience high temperatures in the seedling phase if planted early. Moreover, according to [21] and [22] reported by chickpea productivity is constrained by several abiotic stresses and temperature is one of the most important determinants of crop growth over a range of environments. Study conducted by [23] indicated that the optimal temperature for germination of chickpea is $10-15{ }^{\circ} \mathrm{C}$ and noted that a high germination temperature the mobilization of cotyledon reserves and embryo growth are adversely affected. Low photosynthetic rates and high transpiration rates occur during high temperature stress and tend to reduce plant establishment in chickpea [24]. Similarly, [25] investigated that the pollen viability, pollen germination, tube growth, pollen load and stigma receptivity decreased with increases in temperatures to $45 / 35^{\circ} \mathrm{C}$. The sensitive genotypes were not able to set any pods at $45 / 35^{\circ} \mathrm{C}$, whereas the tolerant genotypes produced only few fertile pods at this temperature. It was concluded that heat stress leads to loss of pollen as well as stigma function and induces oxidative stress in the leaves that cause failure of fertilization and damage to the leaves, respectively.

\section{Conclusion}

The present study showed that all growth, yield and yield component of rice did not significantly affected by additive relay intercropping system and seed proportion in ricechickpea relay intercropping systems. This might be due to early planting of rice in relay intercropping system takes advantage in peak resource demands for nutrients, water, and sunlight for all treatments. However, the results of an experiment for two consecutive years at all test sits confirmed that chick pea after twenty to thirty days from the planting time was completely dried and unable to get seed yield from rice-chickpea relay intercropping experiment probably due to problem of plant architecture, very narrow plant spacing and extremely high temperature during crop growth. Hence, under current crop management practice of rice at Fogera areas, chickpea cannot replace the grass pea in rice-grass relay intercropping system (farmers practice) and relay intercropping of chickpea with rice is not economically important for farmers.

\section{Research Needs}

At Fogera vertisols, relay intercropping of rice with grass pea in additive series in which rice is the main crop component and grass pea is the minor crop component was practiced by farmers to intensify productivity with a limited use of external inputs. Conversely, the present study confirmed that relay intercropping of rice with chickpea in additive series in the above system was considered to be too risky to cultivate. However, this study was conducted only on one chickpea and rice cultivar and for one planting date of the companion crop (chickpea). Thus, for its effective realization, the following valuable recommendations are also suggested: 
- This research was focused on broadcasting of chickpea between rows of rice near to physiological maturity of rice. Further research is essential to evaluate different planting patterns (row and strip relay intercropping) and Planting date of chickpea (time of relayed crop)

- Farmers grow traditional varieties of rice and grass pea with minimum inputs as components to the relay intercropping system; future research should give additional emphasis to evaluate improved varieties of rice (early maturity) and chickpea (early maturity, high temperature tolerance etc.) and improved management practices that can maximize the profitability of the existing cropping system in a sustainable way.

- Future research should also mainly focus on identifying the optimum plant spacing between rows of rice under rice-chickpea relay intercropping system

\section{References}

[1] Francis, C.A., 1986. Introduction: distribution and importance of multiple cropping. Pages 1-20 in multiple cropping systems (Francis, C.A., ed.). Macmillan Publishing Company, New York, USA.

[2] Sanchez, P.A., Palm, C.A., Davey, C.B., Szott, L.T., and Russell, C.E. 1985. Trees as crop plants. Institute of Terrestrial Ecology, Natural Environment Research Council, Proceedings: Impact of Climate Change on Agriculture. 23-25 February, New Delhi, India. Pp. 189-193.

[3] Reddy, M.S. and Willey, R.W., 1981. Growth and resource use studies in an intercrop of peril millet/ground nut. Filed crop Research 4:13-24.

[4] Zhu Youyong, 2000. "Genetic diversity and disease control in rice". International Weekly Journal of Science 406: 718-722.

[5] Food and Agriculture Organization of the United Nations (FAO), 2003. Final Report of the 32nd Session of the Conference: report of the conference of FAO Thirty-second Session, Rome, 29 November - 9 December 2003

[6] Central statistical agency (CSA), 2013. Agricultural sample survey 2012 / 2113, volume III. Report on area and production, Addis Ababa, Ethiopia.

[7] Ethiopian Institute of Agricultural Research (EIAR), 2011.Empowering Farmers' Innovation, Series No. 2: Challenges and Opportunities of Rice in Ethiopian Agricultural Development, Adise Abeba, Ethiopia

[8] Tilahun T., Alemayehu A., Minale L., and Zelalem T. 2008. Effect of seed soaking and incubation on the emergence, growth and yield of rice. In: Ermias A., Akalu T., Alemayehu A.G., Melaku W., Tilahun T., and Wondimu B.(eds). 2008. Procceedings of the $2^{\text {nd }}$ Annual Regional Conference on Completed Crop Research Activities, 18-21 Sep. 2007. Amhara Regional Agricultural Research Institute. B.D., Ethiopia. Pp. 36-40.

[9] Heluf Gebrekidan and Mulugeta Seyoum, 2006. Effects of Mineral N and P Fertilizers on Yield and Yield Components of Flooded Lowland Rice on Vertisols of Fogera Plain, Ethiopia. Journal of Agriculture and Rural Development in the Tropics and Subtropics Volume 107(2): 161-176
[10] Mulugeta Seyoum; Uptake and response of rice (Oryza sativa L.) to nitrogen and phosphorus fertilization under rain fed lowland condition of the Fogera Plain, Northern Ethiopia; Master's thesis; Alemaya University; 2000.

[11] SAS Institute Inc. (2002). JMP-5 Statistical Software, Version 5.Cary, NC, USA.

[12] Preston, S. (2003). Intercropping Principles and Production Practices. NCAT, ATTRA Publication \# Pp 135. Accessed in November, 2014 at attra.ncat.org

[13] Bantie, Y.B., Abera, F.A. and Woldegiorgis, T.D., 2014. Competition Indices of Intercropped Lupine (Local) and Small Cereals in Additive Series in West Gojam, North Western Ethiopia. American Journal of Plant Sciences, 5, 1296-1305.

[14] Yayeh Bitew, 2014. Influence of Small Cereal Intercropping and Additive Series of Seed Proportion on the Yield and Yield Component of Lupine (Lupinus Spp.) in North Western Ethiopia. Agriculture, Forestry and Fisheries 3 (2) 133-141

[15] Muhammad Bismillah Khan and Abdul Khaliq, 2005. Production of winter cereals as relay crops by surface seeding in cotton based cropping system. Journal of Research (Science) 16(2), $79-86$

[16] Jones, R.K. and McCown, R.L. (1983). Research on no-till tropical legume farming strategy. In: Proceedings of Eastern Africa -ACIAR Consultation on Agricultural Research. Nairobi, Kenya, Pp 18-23.

[17] Nelson and. Robichaux, 2006. Identifying plant architectural traits associated with yield under intercropping: Implications of genotype-cropping system interactions. Plant Breeding 116 (2) $163-170$

[18] Arshad Mahmood, Faqir Hussain Anjum and Amjad ali, 2003. Rice planting geometry facilitating relay cropping at zerotillage. International journal of agriculture \& biology 15(4):435-437

[19] Devasirvatham, V D. K. Y. Tan, P. M. Gaur, T. N. Raju and R. M. Trethowan, 213. High temperature tolerance in chickpea and its implications for plant improvement. Crop and Pasture Science 63(5) 419-428

[20] Berger JD, Turner NC (2007) The ecology of chickpea. In 'Chickpea breeding and management'. (Eds. SS Yadav, R.J Redden, W Chen, B Sharma) pp. 47-71 (CAB International Publishing: UK).

[21] Basu PS, Ali M, Chaturvedi SK, 2009. Terminal heat stress adversely affects chickpea productivity in Northern IndiaStrategies to improve thermo tolerance in the crop under climate change. ISPRS Archives XXXVIII-8/W3 Workshop

[22] Gaur PM, Pande S, Sharma HC, Gowda CLL, Sharma KK, Crouch JH, Vadez V (2007) Genetic enhancement of stress tolerance in chickpea: Present status and future prospects. In 'Crop production stress environments: Genetic and management options'. (Eds. DP Singh, VS Tomar, RK Behl, SD Upadhyaya, MS Bhale, D Khare) pp. 85-94. (AGROBIOS International Publishing: Jodhpur, India).

[23] Ellis RH, Covell S, Roberts EH, Summerfield RJ (1986) The influence of temperature on seed germination rate in grain legumes. Journal of Experimental Botany 183, 1503- 1515.

[24] Singh NH, Dhaliwal GS., 1972). Effect of soil temperature on seedling emergence in different crops. Plant and soil 37, 441-444. 
[25] Sanjeev Kumar, Prince Thakur, Neeru Kaushal Jahid A. Malik, P. Gaur \& Harsh Nayyar, 2013. Effect of varying high temperatures during reproductive growth on reproductive function, oxidative stress and seed yield in chickpea genotypes differing in heat sensitivity. Archives of Agronomy and Soil Science 59(6):823-843 